\title{
The Impact of Cooperative Learning Strategy on the Accomplishment of Selected Athletics Skill and Some Physical Abilities among Pupils
}

\author{
Bassam A. Mismar \& Elham M. Al-Harahsha \\ The University of Jordan \\ School of P.E. \\ Researcher, Ministry of Education
}

\begin{abstract}
The study aimed to identify the impact of cooperative learning strategy on the accomplishment of athletics skill (long jump)and some physical abilities. The sample of the study consisted of (20) students from the Syrian refugees affiliated to Jerash district in North Jordan. An instructional program was formed by using cooperative strategy to teach selected athletics activities along with some physical abilities. The program was applied for six weeks in order to identify its impact on improving performance of the pupils in the dependent measures.Quasi-experimental approach was chosen as a research design to test the hypothesis of the study.Statistical methods represented by arithmetic means, standard deviations, variation coefficient, correlation coefficients and t-Test were used for data analysis. The results of the study showed that the instructional program based on cooperative learning strategy has a positive effect on learning athletics skill and showed significant enhancements in the level of physical ability tests in post-test measurements. The researchers recommend applying the instructional program based in cooperative learning to teach different athletics curricula.
\end{abstract}

Keywords: cooperative learning, athletics skill, physical abilities.

\section{Introduction:}

The accelerated development in the educational process is considered as a requirement from all workers in the educational field to use teaching -learning strategies in order to keep pace with the modern era of science and technology, due to the role of these strategies to produce interaction and encourage keeping intellectually and physically hard work in order to reach mastery state. In the field of physical education, which enjoyed specificity compared to other educational fields. cooperative learning strategy is considered to be a student-centered model of teaching, so that the role of the student could be summarized into the following roles: Observing, recording, presenting, data collecting, timers, performance, leadership. where the teacher main role becomes as a facilitator in assigning responsibility for learners in the class(Dyson, Griffin \&Hastle, 2004; Hannon \& Rattliffe, 2004).

Cooperative learning strategy is one of the strategies based on teamwork has been used for more than three decades. In this instance Salvin(1989) stated that the term could be applied to different teaching methods in class where teachers encourage students to cooperate in learning process. In this strategy, teachers need to be well organized through dividing students into small and wellstructure groups, where each group works within its framework by providing opinions, concepts and information in order to master the content of their lessons, providing that the operation is organized, coordinated and based on respecting opinions and acceptance of other variations. Where the role of the teacher is limited to guidanceand strengthening the right behavior. (Salliti, 2006; Hannon and Ratliffe,2004).

Siedentop and Tannehill (2000) stated that working with cooperative learning strategy is one effective instructional format not just type of in class activities that student involved in it, but they will be assigned to groups in order to solve certain problems. Al-Hila (1999)also stated that the objective of cooperative learning strategy is to create an organizational structure for the work of a group of students in the class so that all members of the group indulge in learning according to clear and specific goal and role, making sure that at the end, each member of the group learns the educational subject.

The use of cooperative learning strategy seems to have a positive impact on all the elements of the educational process (Seidentop\&Tannehil, 2000; Silverman \& Ennis, 2003; Dyson, etal,2004; Metzler,2011; Casey,2012). In addition to its impact on the personality of the learner himself from educational, social and psychological aspects. As some researchers indicated, it raises learner competencies to improve his/her level of thinking and the ability to solve daily life problems, and to afford various individual and collective responsibilities. 
One of the important characteristics of cooperative learning, which distinguishes it from other types of learning is that it contributes to the development of the ability to accept different points of view, and opinion, in addition to the elimination of the introversion and isolation of the learner, intolerance of opinion, and subjectivity. It also increases learners' motivation for learning and helps him/her understand and master the learning aspects of the subject, reduces the anxiety and fear associated with the learning process, as well as stabilizing the learner's information in his mind (Mismar \& Al-Harahsheh, 2018).

Studies have been focusing on cooperative learning within the classroom since the beginning of the 1970s based on theories of psychology and social psychology (Slavin, 1990).Different strategies of cooperative learning have been applied and developed in the classroom and in all different types of sciences including the student work method, developed by Slavin based on the theories of psychology and social psychology.(Slavin,1990).

Physical abilities are considered the cornerstone of exercising and mastering most sportactivities and serve as a strong and firm foundation of athletic accomplishments. In this case, attention must be paid to the development of the level of physical abilities of the sports-based system (Abu Odeh, 2009). This would be of value and should be given great attention when we deal with training the early ages children, because of the characteristics of the child's motor, physical, emotional, mental, social in order to affect the formation, development and direction of the future child's behavior (Bar, 2003).

According to some mentioned references (Hannon \&Rattliffe,2004; Metzler,2011; Mismar\& Al-Harahsheh, 2018), the researchers believe that the strategy of cooperative learning, and the use of its advantages and benefits are of important concern, as the researchers believed the strategy could work to develop and improve the technical stages of selected athletics eventsand create a practical and realistic environment that enables the student to process the information given to him by analyzing and re-installing it, and make appropriate adjustments to access new information or derive relationships between parts of the complex activities, in addition to linking between performance and mental imagery without being known to him in advance and without being given by the teacher. Thus, may make this information meaningful to him, which helps to keep the information in mind for long terms, besides it develops the ability to retrieve a sense of visual perception of complex technical stages. The role of the teacher here may be summarized in planning, facilitating, directing and guiding the student.

\subsection{Study problem:}

Through the experience of the researchers in the field of physical education and instruction, they observed a general weakness in the performance of students in public schools in Jordan, especially in some athletics skills. In addition tolack of knowledge about technical aspects among learners when applying different skills, as well as a decrease in the level of their physical abilities. In addition to a paucity of this line of research in teaching athletic skills.

In light of the above mentioned reasons, the researchers considered addressing this problem by identifying the impact of the cooperative learning strategy in measuring the level of the selected athletic skills and some physical abilities among school students in Jordan, this strategy could be of value in enriching the teaching learning processes, as well as facilitating teaching of physical skills.

\subsection{Significance of the study:}

The significance of the study stems from the use of teaching strategies that take into account the different growth characteristics of age group among students and act as a promoter in making students more effective during PE lessons. In addition to the multiple organizational and administrative considerations throughout the instructional program by utilizing cooperative learning strategy, and the challenge of utilizing such strategy in individual events.

\subsection{The importance of the study:}

1. This study deals with a topic that requires intensified efforts in the educational sectors in order to make the educational process successful and to improve the level of students through the use of modern teaching strategies in the schools of the Ministry of Education in Jordan

2. This study examines the role of cooperative learning strategy in measuring the level of some selected athletics skill and some physical ability components among school students in Jordan.

\subsection{Study objective:}

This study aimed to identify:

The impact of the cooperative learning strategy in the level of achievement in some of selected athletics skilland some physical abilities in Syrian refugee students in Jordan. 


\subsection{Study hypothesis:}

There were significant statistical effects of the cooperative learning strategy at the level of $(\alpha \leq 0.05)$ in determining the level of achievement in selected athletics skill and some physical abilities among Syrian refugee students at Jerash governorate in Jordan.

\subsection{Terminology of study:}

- Cooperative Learning Strategy: It is a student-centered teaching strategy, where teachers set the scene to let students work in small heterogeneous groups and encourage them to cooperate together and helping each other in performing the required motor task and to achieve a common learning goal.

\section{Previous studies:}

Al-Shdaifat (2018) conducted a study that aimed at identifying the role of cooperative learning strategy in the King Abdullah II Award for Physical Fitness in developing the creative thinking skills of students in Jordan according to (educational stage, gender, experience) variables. The sample of the study consisted of (65) male and female teachers of physical education in the Ministry of Education for Al-Mafraq -Jordan in the public sector.

To achieve this, the researcher used the questionnaire as a tool to collect data. Also, statistical methods of arithmetic mean and standard deviations, t-test for significance differences, and One-way ANOVA test were used. To achieve the objective of the study, a scale of the development level of creative thinking skills was designed, and the results of the study showed that individuals in the sample obtained a high level of creative thinking on the scale as a whole. As for the variables of the study, the results revealed that there are no statistically significant differences in the level of creative thinking in the dimensions (school level, experience, gender).

A study of (Trajkovic, et al, 2016) aimed to determine the impact of a gymnastics training program at school on fitnessrelated health of young students. The study included 58 young students $(14.82 \pm 0.44)$. A 12 -weeks training program was implemented in a group of adolescents' schools (secondary and primary).The studied variables were selected from the Euro Fit Battery as well as tests to measure abdominal strength, flexibility, upper and lower body strength, speed and agility. The results showed a moderate initial level and a dynamic increase in physical fitness among the participants. The difference between pre-test and post-test also showed a significant improvement in all the variables tested. The researchers therefore recommended participating in gymnastics training as a positive institutional activity for school-age children, from early childhood to adulthood; in addition, the results provide useful information in improving the training of many students involved in gymnastics training in all physical education classes.

Coak (2015) conduct a study entitled "The effect of cooperative learning on learning approach of students with different learning styles" in order to determine the effect of the concept by utilizing some activities on deep learning. The subjects of the study were $(n=39)$ students chosen on purposive way from Turkish Institution. A questionnaire and other tools were used as tools to collect data. The results of the study showed statistically significant differences in post-test scores of the subjects where post-test scores were better than pre-test scores in deep learning approach due to the cooperative learning.

A study conducted by Callado etal (2014) aimed at understanding and analyzing the concept in Spain, and how they implement the concepts in their classes whom were serve as subjects in the study. The researchers utilized some research tools such as questionnaire and documentary analysis technique to collect data. The results of the study revealed that all subjects know the general principles of using the concepts of cooperative learning very well, additionally, they conceive cooperative learning as appropriate methods to differentiate between types of learning and evaluation.

Al-Ma'aytah, (2013) conducted a study aimed at identifying the effect of a proposed training program to improve some fitness elements of some skills. The researcher used the experimental approach for two groups, (experimental and control). The sample of the study was randomly selected. It consisted of (22) female students from the Faculty of Sports Sciences at Mu'tah University, where they were divided into two equal groups. An experimental group which consisted of 12 female students and a control group which consisted of (10) female students. The pre-tests were conducted first and then the training program was applied at 75 minutes for each training unit and then the post-tests were conducted, while the control group applied the traditional program. After conducting the statistical operations, the results of the study concluded that the proposed training program had a positive effect on improving some elements of fitness for some skills in gymnastics, in which the members of the experimental group outperformed the members of the control group. A Study conducted by Goudas and Magotsiou (2009) entitled "The effect of a cooperative physical education program on students' social skills and attitudes towards group work". The purpose of the study was to identify the effect of a program on the dependent variables(student social work and group work attitudes). 
The sample of the study was $(\mathrm{N}=114)$ students in elementary school grades (Six grade) who were divided into two groups experimental and control $(n=57)$. The experimental group received cooperative learning treatment when the $\mathrm{Ss}$ completed some forms of tests and assessments (Children Social Competencies and Feelings towards group work scale) before and after the program. The results showed that some there were some gains appeared in the experimental group pertaining to student social skills and performance on their feelings towards group work.

3. Methodology and procedures: The researchers used the experimental approach in itsquasi-experimental form to suit the nature of this study.

The study population and sample: The study population consisted of (500) Syrian refugee students from spatial centers at Jerash governorate in Jordan. The sample of the study was chosen deliberately (intentionally) from the population $(\mathrm{n}=20)$ who were exposed to the proposed instructional program.

\subsection{Study tools:}

a) The Instructional program:

The proposed instructional program based on the cooperative learning strategy was formed to teach some physical abilities in relation to athletics skill (long jump).It consists of (10) educational units, including some physical abilities in relation to athletics events (long jump).

b) Paper and Pencils to collect data by measuring the dependent variables( the level of achievement in selected athletics skill and some physical abilities).

\subsection{Study variables:}

a) Independent variables:

- Proposed instructional program based on cooperative learning strategy, in its both forms: peers and groups learning.

b) Dependent variables: grades related to some physical abilities and athletics skill(long jump).

\subsection{Statistical treatment:}

The researchers used the following statistical methods to analyze the data by utilizing

(SPSS)Statistical package in Social Science which includes:

1. Arithmetic means and standard deviations.

2. Variation coefficients.

3. Correlation coefficients.

4. Tests for differences ( $\mathrm{t}$-Test).

3.4 Homogeneity of the sample:

Table (1) Arithmetic means, standard deviations and variation coefficient forage, height and weight

\begin{tabular}{|l|l|l|l|}
\hline $\begin{array}{l}\text { Physical } \\
\text { variables }\end{array}$ & Arithmetic mean & $\begin{array}{l}\text { Standard } \\
\text { deviation }\end{array}$ & $\begin{array}{l}\text { Variation } \\
\text { coefficient }\end{array}$ \\
\hline Age & 13.55 & 0.60 & 4.43 \\
\hline Height & 1.49 & 0.04 & 2.68 \\
\hline Weight & 23.55 & 6.45 & 27.39 \\
\hline
\end{tabular}

The table (1) shows the values of the arithmetic means, standard deviations and the variation coefficient for age, height and weight for the Ss. When reviewing the values of the variation coefficient, which refer to the ratio of standard deviation relative to the arithmetic mean, it is found that the highest value of variation coefficient reached (27.39) in weight and since this value (the largest among the values of variation coefficient) was less than (50.0\%) It means that all the deviation values shown reflect acceptable variation values. This indicates that the members of the study sample are homogeneous in the values of these measurements, as it is known that when the value of the variation coefficient is law, this indicates the harmony of the sample of the study in these measurements. 
Table (2) the values of some descriptive statistical indicators of some selected physical abilities in athletics in pre-measurement

\begin{tabular}{|l|l|l|l|l|l|l|}
\hline Physical ability & $\begin{array}{l}\text { Minimum } \\
\text { value }\end{array}$ & $\begin{array}{l}\text { Maximum } \\
\text { value }\end{array}$ & $\begin{array}{l}\text { Arithmetic } \\
\text { mean }\end{array}$ & $\begin{array}{l}\text { Standard } \\
\text { deviation }\end{array}$ & $\begin{array}{l}\text { Variation } \\
\text { coefficient }\end{array}$ & $\begin{array}{l}\text { Skewness } \\
\text { coefficient }\end{array}$ \\
\hline $\begin{array}{l}\text { Bend the arms from } \\
\text { the oblique prone } \\
\text { (repeat. \#) }\end{array}$ & 30.00 & 42.00 & 35.65 & 3.70 & 10.38 & .191 \\
\hline $\begin{array}{l}\text { Bend the trunk to the } \\
\text { front from the long } \\
\text { sitting (cm) }\end{array}$ & 30.00 & 42.00 & 35.65 & 3.70 & 10.38 & .191 \\
\hline $\begin{array}{l}\text { Running Bounce (4 } \\
\text { * 10) m }\end{array}$ & 11.35 & 13.80 & 12.26 & 0.71 & 5.79 & .588 \\
\hline Long jump & 4.00 & 6.00 & 5.15 & 0.67 & 13.01 & -.177 \\
\hline
\end{tabular}

The table (2) shows the values of some descriptive statistical indicators of some selected physical abilities in athletics in pre-measurement. Given the values of the variation coefficient, which indicates the ratio of the standard deviation for the arithmetic mean, it is found that the value of the variation coefficient has reached (13.01) for long jump (the largest among the values of the variation coefficients), this means that all deviation values associated with the abilities shown reflect acceptable values. A thing that indicates that the members of the study sample are homogeneous in the values of these (physical) abilities. As the lower the value was, the greater the consistency of the physical abilities becomes among the study sample. Table (2) also shows a significant statistical indicator to be verified before using the statistical tests, which is to identify the extent to which the distribution of the study variables data is close to the default and normal distribution. This is done through the skewness coefficient as the closest descriptive indicators, where the data of variables are considered close to the normal distribution if they are limited between $(-3$ to +3$)$ standard deviations. It is noted that these values fall within the normal range of skewness coefficients

Table (3) Stability of physical abilities among school students using application and re-application of the test $(\mathbf{n}=17)$

\begin{tabular}{|l|l|l|l|l|l|l|l|}
\hline \multicolumn{2}{|l|}{ Physical abilities } & \multicolumn{2}{l|}{ First application } & \multicolumn{2}{l|}{ Second application } & Correlation \\
coefficient & $\begin{array}{l}\text { Level } \\
\text { significance }\end{array}$ \\
\cline { 2 - 8 } & $\begin{array}{l}\text { Arithmetic } \\
\text { mean }\end{array}$ & $\begin{array}{l}\text { Standard } \\
\text { deviation }\end{array}$ & $\begin{array}{l}\text { Arithmetic } \\
\text { mean }\end{array}$ & $\begin{array}{l}\text { Standard } \\
\text { deviation }\end{array}$ & & & \\
\hline $\begin{array}{l}\text { Bend the arms } \\
\text { from the oblique } \\
\text { prone (repeat. \#) }\end{array}$ & Push-ups & $\mathbf{3 6 . 6 5}$ & $\mathbf{3 . 2 0}$ & $\mathbf{3 5 . 1 2}$ & $\mathbf{5 . 0 6}$ & $\mathbf{0 . 7 9 8}$ & $\mathbf{0 . 0 0 1 *}$ \\
\hline $\begin{array}{l}\text { Bend the trunk to } \\
\text { the front from the } \\
\text { long sitting (cm) }\end{array}$ & Flexibility & $\mathbf{3 6 . 6 5}$ & $\mathbf{3 . 2 0}$ & $\mathbf{3 9 . 8 2}$ & $\mathbf{3 . 2 3}$ & $\mathbf{0 . 8 5 3}$ & $\mathbf{0 . 0 0 1 *}$ \\
\hline $\begin{array}{l}\text { Running Bounce } \\
(4 * 10) \mathrm{m}\end{array}$ & Agility & $\mathbf{1 2 . 0 5}$ & $\mathbf{0 . 5 7}$ & $\mathbf{1 1 . 7 7}$ & $\mathbf{0 . 6 4}$ & $\mathbf{0 . 8 9 0}$ & $\mathbf{0 . 0 0 2 *}$ \\
\hline
\end{tabular}

The results of table (3) indicate the stability of physical abilities among school students in Jordan by using application and re-application test. When reviewing the stability values, it reached (0.798) and the level of significance was $(0.001)$ of the push-ups from prone position. The stability value was $(0.853)$ and the level of significance was $(0.001)$ for sit and reached. Finally, the value of $r$ was $(0.890)$ and the level of significance was $(0.002)$ for running ability. It is noted that the correlation coefficients reached are considered high enough from the statistical point of view in this study. When comparing the values of significance level $(\alpha \leq 0.05)$, it was found that the calculated significance level values were the least indicating that the relationship between the values of pre and post applications of physical abilities is a strong and statistically reached significant relationship. This indicates the high degree of stability of these capabilities within the limits of the exploratory sample used to estimate the stability, and thus the stability of the tests used and their validity for application are concluded. 


\section{Results}

This study aimed to investigate the impact of cooperative learning strategy in achieving some physical ability and athletic skill in long jump among Syrian refugee students at Jerash in Jordan. The results of the study are reviewed below.

\subsection{Testing the hypothesis of the study:}

The research hypothesis: There were significant statistical effects of the cooperative learning strategy at the level $(\alpha \leq 0.05)$ in determining the level of accomplishment in selected athletics skill and some physical abilities among Syrian refugee students in Jerash governorate.

In order to verify this hypothesis, tests and measurements were used to examine the significant differences between the pre, and post trials of some physical abilities related to athletics skills among the sample members. Table (4) shows that.

Table (4): t-test for differences between pre and post measurements of some physical abilities related to selected skills in athletics

\begin{tabular}{|c|c|c|c|c|c|}
\hline Physical ability & measurement & $\begin{array}{l}\text { Arithmetic } \\
\text { mean }\end{array}$ & $\begin{array}{l}\text { Standard } \\
\text { deviation }\end{array}$ & t-value & $\begin{array}{ll}\text { Level } & \text { of } \\
\text { significance }\end{array}$ \\
\hline \multirow{2}{*}{$\begin{array}{l}\text { Bend the arms from } \\
\text { the oblique prone }\end{array}$} & pre & 35.65 & 3.70 & \multirow[b]{2}{*}{4.12} & \multirow[b]{2}{*}{$0.003 *$} \\
\hline & post & 29.95 & 6.90 & & \\
\hline \multirow{2}{*}{$\begin{array}{l}\text { Bend the trunk to } \\
\text { the front from the } \\
\text { long sitting }\end{array}$} & pre & 35.65 & 3.70 & \multirow[b]{2}{*}{14.32} & \multirow[b]{2}{*}{$0.002 *$} \\
\hline & post & 38.75 & 3.81 & & \\
\hline \multirow{2}{*}{$\begin{array}{l}\text { Running Bounce (4 } \\
* 10) \mathrm{m}\end{array}$} & pre & 12.26 & 0.71 & \multirow{2}{*}{6.44} & \multirow{2}{*}{$0.004 *$} \\
\hline & post & 12.02 & 0.67 & & \\
\hline
\end{tabular}

The results of the t-test indicate statistically significant differences at level of $(\alpha \leq 0.05)$ between the physical abilities' means of selected skills in athletics among Syrian refugee students in Jerash governorate between the pre and post measurements. Based on the calculated (t) value which reached (4.12), with (0.003) level of significance for the push _ups inprone position. Also, the value of the calculated(t) reached (14.32) with(0.002) level of significance for sit and reachedability and (6.44) with(0.004) level of significance for running ability. When comparing the values of the significance level to 0.05 , it was found that the calculated significance level values were the least indicating that the differences between the pre and post measurements of physical abilities are substantial and statistically significant, where the significance of preference was to the post measurement, whose mean values were greater compared to the pre-measurement as shown in the table (4).

Table (5): t-test of the differences between the means of the long jump in athletics among Syrian refugee students in Jerash governorate

\begin{tabular}{|l|l|l|l|l|l|l|}
\hline $\begin{array}{l}\text { Skills in } \\
\text { athletics }\end{array}$ & Measurement & Number & $\begin{array}{l}\text { Arithmetic } \\
\text { mean }\end{array}$ & $\begin{array}{l}\text { Standard } \\
\text { deviation }\end{array}$ & t-value & $\begin{array}{l}\text { Level of } \\
\text { significance }\end{array}$ \\
\hline \multirow{2}{*}{ Long jump } & pre & 20 & 5.15 & 0.67 & \multirow{2}{*}{12.90} & $0.005^{*}$ \\
\cline { 2 - 7 } & post & 20 & 7.30 & 1.13 & \\
\hline
\end{tabular}

The results of $\mathrm{t}$ test indicate that there are statistically significant differences at the significance level $(\alpha \leq 0.05)$ between the long jump means in athletics among Syrian refugee students in Jerash governorate between the pre and post measurements based on the calculated value of $t$ which reached (12.90), with a (0.005) level of significance. It is noted that the value of the calculated significance level was less than $(0.05)$ which means that the differences between the pre and post-measurements of the long jump skill in athletics are substantial and statistically significant. Where the significance of preference of these differences was for the post measurement, whose mean values were greater as shown in Table (5).

The results of the study showed a positive and statistically significant effect for the use of cooperative learning method in developing the physical abilities and athletic skill of Syrian students in Jerash governorate in Jordan. The researchers can explain this result by referring to the nature of this method of learning as it adopts the system of small groups led by a student and it is based on the interaction and participation between all members of the group in the completion of the work or the task. Thus, the performance or tests must be performed by everyone, as well as everyone cooperates with each member within the group in the accomplishment of the task required, for example, when the student performs 
a certain physical ability task or skill, everyone should encourage him and provide positive reinforcement. The assumption that everyone performs this duty requires the individual's psychological readiness to prove himself and his achievements, which makes this student exert his best effort to prove himself and his success in front of his colleagues, as well as to prove his ability to perform the required exercise or motor task. In the opinion of the researchers, the exchange of roles in the leadership of the group requires the student to be successful in order to represent the qualities of the model leader that performs exercises optimally. The researchers pointed out that this strategy is based on the principle of participation and cooperation between all, so even if a student is conceived himself to be weak in his physical abilities or performing pertinent task he may find himself within the group encouragement, challenging, so he shall push him up to perform as best as possible. The results of the study conformed with the studies utilized such a strategy of cooperative learning in some dependent measures whether they relate to achievements or accomplishments, such as Al-Maaytah (2013); Calladoetal (2014); Coak (2015) Trajkovic, et al, (2016).

\section{Recommendations}

1. To use cooperative learning strategy in teaching athletics curricula in particular and other physical education curricula in general.

2. The need to use instructional programs based in cooperative learning to develop students' skills in some athletics and motor abilities.

3. An attempt should be given to create an effective partnership between the teacher and the students besides the use of educational strategies commensurate with the abilities, tendencies, desires and needs of students to contribute to the development of self-motor, mental and emotional skills.

4. To utilize the results of the study in opening the way for the specialists to design programs in physical education to keep pace with scientific and technological development.

\section{List of References}

Abu Odeh, M. (2009), The effectiveness of a proposed training program to improve the physical abilities of some ground movements among students of the Faculty of Physical Education, Al-Aqsa University, Gaza, unpublished Master Thesis, Al-Azhar University, Gaza, Palestine.

Al-Hilah, M. (1999). Educational Design, Dar Al-Masira, Amman: Jordan.

Al-Salliti, F. (2006). Critical and Creative Thinking Cooperative Learning Strategy in Creative Teaching of Reading and Texts,Modern Book World, Jadara for International Book, Book World, Cairo.

Bar, O. (2003). Die Epidemie der AdipositasimKindes- und Jugend alter SchlagenSiemit sport licherAktivitaetzurueck, Sports Science Exchange, (6): 1-8.

Callado, C. etal (2014.) Cooperative learning in physical education. Movimerto,Porto Alegre, 20(1), 239-257.

Casey, A. (2012). Cooperative learning through the eyes of teachers,researchers, and students. In B. Dyson; A. Casey(eds). Cooperative learning in physical education; A research Approach, London, Routlege.pp. 75-87.

Colak ,E. (2015). The effect of cooperative learning on learning approach of students with different learning styles.Eurasian Journal of Educational Research (59), 12-34.

Dayson, B. (2004). Sport education: Tactical games, and cooperation learning. Theoritical and pedagogical considerations.Quest, $156-226-240$.

Hannon, J. Ratliffe, T. (2004). Cooperative Learning in Physical Education. J. of Physical and Sports Educators, 17 (5), 29-32.

InternatiIonal Athletics Federation (1992), Foundations of Education and Training, Cairo: Regional Development Center.

International Amateur Athletics Federation (1995), Athletics Bulletin, Cairo: Regional Development Center, No. 15.

Goudas,M.\&Magotsiou,E. (2009). The Effect of a cooperative physical education programo $\mathrm{n}$ students social skills. $J$. of Applied Sport Psychology,21 (3).

Metzler,M. (2011).Instructional model for physical education. Scolt,AR.HolecombHethaway.

Mismar, B. andShdefat, I. (2018). The impact of cooperative learning strategy on the level of physical,skill and cognitive abilities of selected gymnastics and athletics skills of Syrian refugee students in schools of Jerash, Unpublished Doctoral Dissertation, The University of Jordan.

Slavin, R. E (1990). Cooperation Learning Theory Research and Practice. England Cliffs, NJ. Prentice-Hall.

Salvin, R. E. (1989). Developmental and motivational Perspectives on Cooperative

Learning: A reconciltation. Child Development, 58,1161-1167. 
Shdefat, M. (2018). The Role of Cooperative Learning Strategy in King Abdullah II Award for Physical Fitness in Developing Students' Creative Thinking Skills in Jordan, Accepted for Publication in Jerash. Journal of Research and Studies, Jerash University.

Siedentop,D.\& Tannehill (2000). Development of teaching skills in Physical education. Mountain View, California;Mayfield.

Silverman,S.\& Ennis(2003).Student learning in physical education; applying research to enhance instruction. Champaign,IL,Human Kientics. 